\title{
When Does Aid Conditionality Work?
}

\author{
Gabriella R. Montinola
}

Published online: 14 July 2010

(C) The Author(s) 2010. This article is published with open access at Springerlink.com

\begin{abstract}
Does aid conditionality - the setting of policy goals in exchange for access to aid - promote reform? Many studies on the impact of aid and reform suggest not. However, few explicitly examine whether the impact of aid on reform is mediated by recipient regime type. I argue that conditional aid is effective but its efficacy depends on recipient countries' level of democracy because the value of aid to governments depends on the degree to which it helps them maintain power, and recent work shows that the marginal impact of aid on political survival increases with level of democracy. I test this argument on data from 68 countries over the period from 1980 to 1999. I focus on the impact of IMF and World Bank aid on fiscal reform, one of the most commonly stipulated conditions in aid-for-policy arrangements. I find that aid from the Bretton Woods institutions promotes fiscal reform, but only in more democratic countries.
\end{abstract}

Keywords Aid conditionality $\cdot$ Democracy $\cdot$ Policy reform

For over two decades, international financial institutions, such as the International Monetary Fund (IMF) and the World Bank, have been tying disbursement of their aid to policy reform in recipient countries. The practice, referred to as conditionality, was initially used only by the IMF, which conditioned its loans on countries' reducing their fiscal and current account deficits. Since the 1980s, however, the World Bank began to tie disbursal of its funds to structural adjustment, which included measures similar to those required by the IMF as well as privatization and public sector reform (Koeberle 2003). Soon thereafter, bilateral donors began to make disbursement of their aid conditional on recipients being "on track" with IMF and/or World Bank programs (Dijkstra 2002).

Since its inception, conditionality has generated intense debate. For many years, proponents of conditionality argued that unless recipient countries adopted market-

G. R. Montinola $(\square)$

Department of Political Science, University of California, Davis, Davis, CA, USA

e-mail: grmontinola@ucdavis.edu 
oriented policies, foreign aid intended to promote development would simply prop up inefficient governments (World Bank 2005). Conditioning aid on policy reform was thus intended to make development assistance more effective and increase living standards in recipient countries. Critics of conditionality argued, however, that the market-oriented policies tied to aid might promote development but only at the expense of the poor majority in aid recipient countries (e.g., Fine, Lapavitsas, and Pincus 2001). Fiscal austerity measures would reduce the already low living standards of the poor. Trade liberalization would ruin domestic industries and increase unemployment. Capital account liberalization would open up less developed countries to investments from multinational corporations (MNCs), but the benefits of these investments would accrue only to the MNCs and a small group of elites in aid recipient countries.

These arguments, for and against conditionality, assumed that the practice would be effective at promoting policy change, but as conditionality became more common, this assumption was increasingly called into question. Many countries that received aid conditional on policy change did not develop as expected. Early critics of conditionality maintained that this was due to the policies tied to aid. But proponents began to attribute aid recipients' lack of development to their failure to implement fully policy reforms (e.g., Kuczynski Godard and John 2003). The problem, as they saw it, was not with the content of conditionality but with the failure of the practice to promote policy change.

Has aid conditionality failed to promote market-oriented policies? Studies on the implementation of IMF and World Bank programs paint a dismal picture. One study of IMF programs from 1974 to 1984 shows that out of 30 programs, only 14 were completed, and of those completed, less than half were implemented in their original form (Haggard 1985). A more recent study of IMF programs from 1992 to 1998 shows a completion rate of 56\% (Ivanova et al. 2001). A similar study of World Bank structural adjustment programs from 1980 to 1995 shows that only two thirds of programs were completed (Dollar and Svensson 2000).

On the basis of this poor record, many scholars and policymakers are now calling for the abandonment of conditionality (Collier et al. 1997; Killick, Gunatilaka, and Marr 1988). I argue, however, that it is premature to abandon the practice altogether. Most work shows only that, on average, aid does not promote policy change. While many examples of failed adjustment exist, and the long-term effects of structural adjustment programs are debatable, some governments have adopted adjustment policies as conditions for aid from the IMF and World Bank. In 1991, the Chamorro government of Nicaragua (1990-1996) adopted stabilization and structural adjustment measures after signing agreements with the Bretton Woods institutions, and Nicaragua's government deficit as a percent of GDP dropped from 20\% in 1990 to $8 \%$ in 1996 (Dijkstra 1999). In 1986, the Paz Estennsoro government of Bolivia (1985-1989) carried out fiscal reforms, including a wage freeze and job cutbacks in the public sector, with the initiation of adjustment lending from the IMF (Bird 1992; Solimano 1990). Mauritius provides another example of successful stabilization and adjustment. In the 1980s, successive democratic governments in Mauritius completed five IMF standby arrangements and two World Bank structural adjustment programs. The policies adopted by the Mauritian governments under the auspices of the IMF and World Bank included cuts in government spending, 
adoption of a new value-added tax, and the holding of wage increases below rates of inflation (Bräutigam 1997). These examples suggest that conditional aid may be effective, if only under some circumstances.

I argue that the efficacy of conditional aid depends on recipient countries' level of democracy because the value of aid to governments varies across regime type. If governments seek primarily to maintain power, they should value aid, and comply with conditions, to the degree that it helps them survive in office. Recent work shows that the marginal impact of aid flows on political survival is greater for democrats than autocrats. More specifically, Bueno de Mesquita et al. (2003) and Kono and Montinola (2009) argue that political competition compels democratic leaders who want to maintain power to spend almost all aid as they receive it, while autocrats are able to stockpile much of the aid they receive for future use and still maintain power. Since democrats are unable to stockpile as much aid as autocrats, current aid disbursements have a greater impact on their survival prospects. ${ }^{1}$ Because aid disbursements are more valuable to democrats than autocrats, donors should have more leverage over the former. Consequently, aid conditionality is more likely to be effective in democracies than autocracies.

I test this argument on data from 68 countries over the period from 1980 to 1999. I focus on the impact of IMF and World Bank aid on fiscal reform, one of the most commonly stipulated conditions in aid-for-policy arrangements. Using an errorcorrection model, I find that IMF and World Bank aid promotes fiscal reform, but only in more democratic countries.

I probe these estimates further to ensure their robustness. First, I consider a powerful alternative explanation implied by the work of Stone (2004), who argues that the degree of conditionality imposed on aid recipients is a function of international politics. Stone's analysis implies that conditionality may not be binding on recipients important to developed countries who have significant influence over the Bretton Woods institutions. Less stringent conditionality may therefore be the reason some countries are less likely to reform. I show that my results hold when controlling for the value of developing countries to influential developed country patrons. Second, I also consider the possibility that my results are biased by endogeneity between aid, regime type, and fiscal performance. I perform two-stage least-squares instrumental variable analyses to correct for endogeneity bias, and the results of my analysis are essentially unchanged. Finally, before concluding, I consider the possible tension between my work and work by Nooruddin and Simmons (2006), who find that the relationship between IMF program participation and the composition of government spending is conditional on countries' level of democracy.

Determining when aid conditionality works is of practical as well as theoretical interest. At a summit in 2005, the Group of Eight (G8) nations committed to increase aid to Africa by 2010, from $\$ 25$ billion to $\$ 50$ billion a year (Stevenson 2005). For years before the summit, foreign aid was in decline, and aid groups were concerned with "donor fatigue." Disappointment with the performance of aid was one often

\footnotetext{
${ }^{1}$ In their work on IMF program participation and recipient governments' political survival, Smith and Vreeland (2006) find that the effect of the former on the latter increases with recipient governments' degree of democracy. Their work similarly implies that conditionality should be more effective on democratic leaders.
} 
stated reason for this donor fatigue. Identifying when conditionality works is thus one step toward ensuring that donors' aid is used for its intended purpose, and improvements in the performance of aid should help ensure donors' sustained commitment to aid. My work suggests that if donors want to improve the efficacy of their conditional aid, one way would be to provide aid only to democracies.

\section{Aid Conditionality and Policy Reform}

How might conditional aid promote reform? Models of conditionality (Mosley 1992; Mayer and Mourmouras 2004) generally assume that the proximate goal of governments is to maintain power. ${ }^{2}$ Governments survive in power by providing policy benefits in exchange for support. The policies that they adopt tend to favor special interest groups rather than the country as a whole. Most special interest groups secure their preferred policies even if they represent only a small fraction of the population because they are well-organized and able to provide governments with monetary contributions that help the latter survive in office. In authoritarian settings, special interest groups, such as the military, also secure their preferred policies because they help governments survive by repressive means. In this context, aid conditioned on reform can promote policy change by helping governments weather the "adjustment" costs of reforms that would reduce benefits to special interest groups. This suggests that governments' compliance with donors' policy conditions would depend on the amount of aid offered relative to the expected costs of moving policy away from those preferred by special interest groups. These models of conditionality thus imply that, all else equal, higher levels of aid will lead to more policy reform, as governments will be better able to compensate losers from reform while maintaining power.

Research on aid and reform, however, does not consistently support these models. Some studies show that aid recipients have adopted market-oriented reforms (Koeberle 2003). Others show that aid has no significant impact on policy. Yet others show that aid reduces incentives for reform. I argue that results from these studies are mixed in part because they do not consider the possibility that the effects of aid conditionality are themselves conditional, i.e., that the effectiveness of conditional aid may vary across recipient countries. Although conditional aid should facilitate reform, responsiveness to conditionality may differ depending on recipient countries' domestic political institutions. In particular, I argue that recipient governments' willingness to comply with policy conditions depends on the degree to which aid promotes their political survival, and since the impact of aid on government survival increases with recipient country's level of democracy, governments' responsiveness to conditionality should increase with recipient countries' level of democracy. ${ }^{3}$ Because this argument

\footnotetext{
2 These models differ in many respects. I discuss only their common characteristics, which are sufficient to explain why governments might need conditional aid to adopt reforms.

${ }^{3}$ A number of studies examine the relationship of recipient country characteristics, including regime type, and implementation of IMF or World Bank programs (e.g., Haggard 1985; Remmer 2004; Dollar and Svensson 2000). Since these studies focus only on countries in adjustment programs, they implicitly consider the effect of recipient characteristics, conditional on participation in such programs. They do not consider, however, whether responsiveness to conditionality depends on the interaction of the amount of aid provided and regime type.
} 
is based on the political survival model of Bueno de Mesquita et al. (2003) and its extension by Kono and Montinola (2009), I briefly summarize these works below.

In the Bueno de Mesquita et al. (2003) model, leaders survive in office by providing supporters with a mix of private and public goods. How much of each good a leader must provide depends on the size of the winning coalition (W), i.e., the set of individuals whose support is needed to gain and maintain power. The size of $\mathrm{W}$ determines the relative cost of the two types of goods: as $\mathrm{W}$ increases, private goods become more expensive because they must be given to more individuals while public goods become relatively cheaper because, being non-excludable, they can be provided to many people at fixed cost. Leaders thus spend more on private goods when $\mathrm{W}$ is small but more on public goods when $\mathrm{W}$ is large. Because private goods are enjoyed only by members of $\mathrm{W}$, whereas public goods are enjoyed by everyone, the cost of exclusion from $\mathrm{W}$ falls as $\mathrm{W}$ increases in size.

Because membership in $\mathrm{W}$ confers access to valuable private goods, members of $\mathrm{W}$ are reluctant to defect to challengers even when the latter offer them more goods than the incumbent does. After taking office, the challenger will form a new winning coalition that may or may not include the defector. The risk of being excluded from the challenger's coalition thus creates a "loyalty norm" (Bueno de Mesquita et.al. 2003:65) that allows incumbents to offer less than they could in the absence of this risk. Because loyalty strengthens as $\mathrm{W}$ falls, incumbents spend less overall on their supporters and keep more for themselves as $\mathrm{W}$ becomes smaller.

Because loyalty allows leaders to maintain support with fewer resources, it also allows them to accumulate "slack resources"- the difference between available and expended resources.

These resources can be used to keep supporters loyal in the event of future recessions or other negative shocks to the system. Slack resources thus help leaders survive. Because loyalty increases as $\mathrm{W}$ falls, leaders in small-W systems can accumulate more slack resources than leaders in large-W systems. Leaders in small$\mathrm{W}$ systems are thus more likely to survive.

Since foreign aid is a resource that, once disbursed by donors, is generally at the disposal of recipient country leaders, ${ }^{4}$ the Bueno de Mesquita et al. (2003) model implies that aid's impact on political survival could vary depending on the size of W. In small $\mathrm{W}$ systems, leaders that receive aid can stockpile much of it for future use against negative shocks, thus improving their survival prospects. In large W systems, leaders must expend most foreign aid as it becomes available and may lack resources when negative shocks arise. Thus, foreign aid should help leaders in small W systems more than those in large W systems, at least in the long-run.

Kono and Montinola (2009) extend the Bueno de Mesquita et al. (2003) model, explicitly incorporating aid's impact on political survival. In addition to modeling aid's impact across systems of different coalition size, they distinguish between the short-run effects of current aid disbursements and the long-run effects of cumulative aid on leaders' survival. Their model confirms the implication of work by Bueno de

\footnotetext{
${ }^{4}$ Earmarking aid for specific sectors or projects does not necessarily constrain recipient country governments. Many studies show that aid is fungible, i.e., governments that receive earmarked aid reduce their own resources to the targeted sectors or projects and use them elsewhere (Feyzioglu et al. 1998; Pack and Pack 1993).
} 
Mesquita et al. (2003) regarding the long-run effect of aid on survival: if leaders in small W systems can stockpile aid as slack resources, while leaders in large W systems must expend all aid as they receive it, aid accumulated over time helps the former survive in office longer than the latter. Kono and Montinola (2009) also show, however, that since larger aid stocks lower the marginal impact of additional resources, current aid disbursements have the opposite effect: current aid helps leaders in large W systems more than those in small W systems.

Consistent with their theory, Kono and Montinola (2009) show empirically that, while cumulative aid increases the survival prospects of leaders in small $\mathrm{W}$ systems, it has no significant effect on those in large W systems. Conversely, current aid disbursements promote the survival of leaders in large W systems but do little for those in small W systems. In effect, below a threshold size of $\mathrm{W}$, current aid has no effect on leaders' survival; but above this threshold, larger aid disbursements increase the probability of leaders' survival.

The work of Kono and Montinola (2009) has implications for the efficacy of conditional aid. If, as argued above, the value of aid to recipients depends on the degree to which aid promotes political survival, then their work suggests that conditional aid should give donors substantial influence over leaders in large W systems. This is because aid disbursements always help the latter survive in office. Moreover, donors' influence over leaders in large W systems should not decline over time, even as the former's cumulative aid tally mounts because leaders in large W systems cannot stockpile aid from previous years. Any delays in aid disbursement, or reductions in aid from previous years, increase the probability that leaders in large W systems will lose power. Thus, leaders of large W systems will always value aid highly, and donors will have a consistent source of influence over them.

In contrast, efforts to use foreign aid to influence leaders in small $\mathrm{W}$ systems are ultimately self-defeating. Because the risk of exclusion from the winning coalition is higher in small-W systems, members of the current winning coalition in these systems are more likely than those in large $\mathrm{W}$ systems to temper their demands. This allows leaders in small W systems to keep much of the aid that they receive as slack resources, which they can use to purchase support in case of future negative shocks to the system. Thus, each aid disbursement to leaders in small W systems contributes to their slack resources and reduces the marginal value of additional current and future aid. Leaders in small W systems may even be able to stockpile sufficient slack resources from previous aid disbursements such that additional aid would no longer have an impact on their survival prospects and will thus be of little value to them. Hence, the more aid donors give to leaders in small $\mathrm{W}$ systems, the less influence they will have over them.

This is not to say that leaders in small $\mathrm{W}$ systems are not interested in receiving aid. In the long run, the more aid leaders in small $\mathrm{W}$ systems accumulate the greater is their probability of survival (Kono and Montinola 2009). I argue only that, on average, leaders in these systems will be less sensitive than leaders in large W systems to complying with aid conditionality because the marginal benefit from aid flows in any given year is lower for the former than the latter. In sum, conditional aid can work, but its efficacy should depend not only on the amount of aid offered but also on winning coalition size. 
Note that winning coalition size is conceptually related to regime type. A larger $\mathrm{W}$ implies representation for a larger proportion of the population, which is one defining feature of democracy. Thus, the models discussed above imply that the efficacy of conditional aid depends on regime type. More specifically, they imply that autocrats-incumbents in small W systems-are better able to stockpile resources than democrats - incumbents in large W systems, so that the value of each additional dollar of aid is smaller for autocrats than democrats. Autocrats should therefore be less sensitive to conditionality and more likely to avoid or delay reforms stipulated in aid-for-policy arrangements. I thus propose to test the following hypothesis: the impact of conditional aid on policy reform will increase with recipient governments' level of democracy.

\section{Analysis}

I test my hypothesis on the effects of conditional aid by focusing on fiscal reform. Fiscal policy discipline often ranks first in the typical reform package promoted by Washington-based institutions such as the International Monetary Fund and the World Bank. While the number of conditions that aid recipients must agree to has increased through time, fiscal reform continues to be a main target of donors. Thus, I investigate whether the impact of conditional aid on fiscal performance increases with level of democracy.

I define fiscal reform as measures governments take to improve their fiscal balance. These include measures to reduce expenditures, such as eliminating subsidies, reducing public investment, and reducing government employment, as well as measures to increase revenues, such as the adoption of new tax laws or better tax collection procedures. Improvements in budget balances due solely to aid transfers are thus not considered reform because they do not reflect any changes in domestic policies.

The theory on which my hypothesis is based argues that autocratic leaders are able to stockpile resources that they can use to keep supporters loyal in the event of negative shocks.

If autocrats choose to accumulate these resources by generating fiscal surpluses, then one would expect aid to generate greater improvements in budget balances in autocracies. I argue, however, that autocrats are more likely to stockpile resources in less transparent ways. Many transfer resources to non-state institutions directly under their control. These institutions include political parties, charitable organizations, and dummy corporations. Funds stockpiled in these non-state institutions can then be disbursed during elections or in times of crisis. Other leaders transfer resources to overseas bank accounts and use the funds to purchase support when necessary. These transfers may simply be unrecorded or are likely to show up as expenditures on the government's accounts. Thus, stockpiling by autocrats will not be associated with improvements in fiscal balances, and may even show up as generating deficits.

I measure fiscal reform in terms of the budget balance- the difference between country $i$ 's government revenues and government expenditures at time $t$ as a percentage of gross national income, i.e., $\left(\left(\right.\right.$ revenues $_{i t}-$ expenditures $\left.\left._{i t}\right) / \mathrm{GNI}_{i t}\right) \times 100$. The measure of revenues that I use to calculate governments' fiscal position 
excludes grants from foreign governments and international organizations. I exclude grants to ensure that apparent improvements in the budget balance reflect changes in domestic taxes and/or spending, rather than the inclusion of aid in the budget. Positive values on Budget $_{i t}$ thus indicate fiscal surpluses excluding grants; similarly, negative values indicate deficits excluding grants. In the subsequent analyses, the dependent variable is the change in the budget balance from time $t-1$ to $t$. Positive values on $\Delta$ Budget $_{i t}$ thus indicates improvements in recipients' fiscal balances, i.e., larger surpluses or smaller deficits as a proportion of gross national income. Data for Budget $_{i t}$ are from the Global Development Network Growth Database.

To measure conditional aid, I use net disbursements of IMF and World Bank official development assistance (ODA). ODA is defined as official grants and loans at concessional rates offered for the purpose of promoting economic development. I focus on aid from the IMF and World Bank for a number of reasons. First, they have been the most likely donors to condition their aid on fiscal reform. Although fiscal policy was initially the responsibility of the IMF, ODA from the two institutions has almost always been tied to fiscal reform since 1980 when the World Bank introduced Structural Adjustment Loans (Koeberle 2003). A study by Dreher (2002) shows that $80 \%$ of World Bank programs between 1980 and 1988 included conditions concerning fiscal policy, and those that did not were often tied to recipients being "on track" with IMF programs (Koeberle 2003). Second, although the two institutions are distinct entities, they have increasingly worked together since the 1970s. While each institution eschews legally conditioning its disbursements on conditions of the other, they often engage in less formal means of "crossconditionality" (Feinberg 1988). Consultations between the two institutions occur from the staff level to the level of the Bank's President and the Fund's Managing Director. Each institution prepares its programs jointly with staff members from the other institution (Ahluwalia 1999). The result of this collaboration has been a close link between Bank and Fund loans. Feinberg (1988:554) shows, for example, that "only three of all the World Bank sector loans signed during fiscal years 1979-1985 occurred in countries not engaged in Fund programs." Finally, while one of the IMF's main purposes is to provide short-term financial assistance to member nations, as early as 1974, the institution recognized that the problems of many developing countries required longer-term programs at more concessional terms. Since then the IMF's financing has moved closer to that of the World Bank. It has established a number of facilities that offer assistance over longer periods, and on highly concessionary terms, similar to those of the World Bank (Feinberg 1988; Ahluwalia 1999). ${ }^{5}$ I express the conditional aid measure as a percentage of gross national income because the degree to which leaders comply with aid conditionality should depend on the value that they place on aid disbursements and the value of aid to leaders depends on the number of citizens whose support must be purchased as well as their income level. For a given number of citizens, aid will go further if citizens are poorer. For a given income level, aid will go further in countries with fewer

\footnotetext{
${ }^{5}$ These facilities include the Extended Fund Facility which provides assistance over a 3-year period and extends repayment to between four and 10 years, and the Trust Fund, Structural Adjustment Facility and Enhanced Structural Adjustment Facility which make loans at near-zero interest rates repayable over a period of 5-10 years.
} 
citizens. Since gross national income (GNI) is the product of population and per capita income, it controls for both. I log the measure to reduce skewness and because I expect aid to have diminishing marginal returns on reform. Bretton Woods Aid ${ }_{i t}$ is thus the natural logarithm of net disbursements of IMF and World Bank aid to country $i$ at time $t$ as a percentage of country $i$ 's GNI. ${ }^{6}$ Data on IMF and World Bank aid are from the OECD's Development Assistance Committee Online Databases.

I measure Democracy it $^{-}$country $i$ 's level of democracy at time $t$ - in two ways. First, I use Bueno de Mesquita et al. (2003) measure of the W. The measure is based on the openness and competitiveness of executive recruitment and ranges from 0 to 1 with 1 indicating the most competitive systems. Second, I use the dichotomous regime type measure from Przeworski et al. (2000), as updated by Cheibub and Gandhi (2004; hereafter, ACLP measure). The original ACLP regime measure is coded 1 for dictatorships and 0 for democracies. I reverse the coding for ease of presentation. Thus, the measure is coded 1 if (1) the country's chief executive is directly or indirectly elected; (2) the legislature is elected; and (3) more than one party contests elections. ${ }^{7}$ It is coded 0 , if a regime fails to meet any of these conditions.

To determine whether conditional aid's impact on fiscal reform depends on recipients' level of democracy, I include an interaction term-Bretton Woods Aid*Democracy - the product of Bretton Woods Aid ${ }_{i t}$ and Democracy ${ }_{i t}$. A positive coefficient on Bretton Woods Aid*Democracy would support my hypothesis. It would indicate that the effect of aid on a country's fiscal balance increases with level of democracy. In other words, an increase in aid should have a larger positive impact on the budget balances of democracies than on those of autocracies.

I control for several conditions that have been posited to influence fiscal performance. First, deteriorating terms of trade could adversely affect a country's fiscal balance directly through reduced export revenues or indirectly through lower income tax receipts from exports. Conversely, positive terms of trade shocks should boost revenues and promote fiscal surpluses. Thus, I include a variable Terms of Trade $_{i t}$ the ratio of country $i$ 's export price index to its import price index at time $t$ and expect its coefficient to be positive.

Second, exposure to international trade can influence a country's fiscal balance through different channels. Trade liberalization may cause fiscal deficits, at least in the short run, if governments are highly dependent on trade taxes. In the long run, higher trade volume due to more liberal policies should boost revenues. Furthermore, trade openness reinforces the effects of fluctuations in terms of trade. Since the hypothesized effects of trade openness on fiscal policy through these different channels are somewhat contradictory, which effect will dominate is an empirical question. I thus include a measure of Trade Openness $i_{i t}$ the sum of country $i$ 's exports and imports as a percentage of its gross domestic product at time $t$.

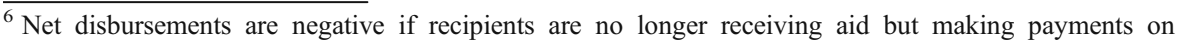
previous concessional loan disbursements. I treat recipients with negative net disbursements like those receiving no aid. The variable is coded as zero, because the former like the latter are not subject to conditions. It should be noted, however, that I also performed the analyses using the untransformed net disbursements measure, and the results were essentially unchanged.

${ }^{7}$ For a detailed description of the coding for this variable, see Przeworski, et.al. (2000:18-30).
} 
Third, less developed countries have relatively inefficient fiscal systems and may therefore be more prone to budget deficits. Thus, I include a measure of economic development-Per Capita Gross National Income. The indicator is measured in purchasing power parity terms and logged to reduce skewness. I expect it to have a positive relationship with fiscal performance. I also control for changes in the state of the economy as measured by annual changes in per capita GNI. Changes in per capita GNI are also expected to have a positive relationship with fiscal performance. During recessions, fiscal balances are likely to deteriorate due to reduced tax receipts as well as increased spending due to governments' countercyclical policy. During economic boom times, fiscal balances are likely to improve. Finally, I control for country fixed effects to control for the effects of unobservable characteristics that may affect both fiscal policy and regime type. ${ }^{8}$

I test my conditional aid hypothesis on a sample of 68 countries from 1980 to 1999 (see Appendix for a list of countries in the sample). I focus on the period since 1980 because this is when the World Bank joined the IMF in emphasizing fiscal reform, and the World Bank provides substantially more ODA than the IMF. ${ }^{9}$ I estimate an error-correction model of the following form:

$$
\Delta \text { Budget }_{i t}=\beta_{0}+\beta_{1} \text { Budget }_{i, t-1}+\gamma \Delta \mathrm{X}_{t}+\lambda \mathrm{X}_{t-1}+\varepsilon_{i t}
$$

where $\Delta$ Budget $_{i t}$ is the annual change in the budget balance as a proportion of GNI, Budget $_{i, t-1}$ is the 1-year lag of the budget balance as a proportion of GNI, $\Delta X_{t}$ is a vector of annual changes in all right-hand side variables, $X_{t-1}$ is a vector of 1-year lags in all right-hand side variables, and $\gamma$ and $\lambda$ are vectors of coefficients for the first-differenced and lagged variables, respectively.

I use an error-correction model because it imposes fewer assumptions than other timeseries estimators regarding the timing of effects of right-hand side variables (De Boef and Keele 2008). Since aid is generally disbursed in exchange for policy commitments, the impact of aid on fiscal outcomes may not occur immediately. Even if policy reforms are enacted shortly after aid disbursement, there may be a lag before the effects of reforms are reflected in fiscal outcomes. Moreover, if policy reforms are adopted sequentially, the effect of aid on reform may be distributed over many years. Error-correction models are useful because they allow us to estimate right-hand side variables' immediate effects as well as their lagged effects distributed over future periods. The right-hand side variables' immediate effects are given by $\gamma$, their effects after 1 year are given by $\lambda$, and their total effects or long-run multipliers (LRMs), which include both immediate effects and those that occur over future time periods, are calculated by dividing the coefficients of the right-hand side variables by the coefficient on the lagged dependent variable. To correct for heteroskedasticity, I use robust standard errors.

Table 1 presents results of the analyses. Models 1 and 2 show the unconditional effects of Bretton Woods aid on the budget balance. Models 3 and 4 present the effects of Bretton Woods aid conditional on recipient countries' level of democracy. Models 1 and 3 use the winning coalition measure for regime type while models 2

\footnotetext{
${ }^{8}$ The data for terms of trade are from the Global Development Network Growth Database (Easterly 2001). Data for trade openness and per capita gross national income are from the World Bank's World Development Indicators (WDI).

${ }^{9}$ During 1980-1999, the World Bank provided over seven times more ODA than the IMF.
} 


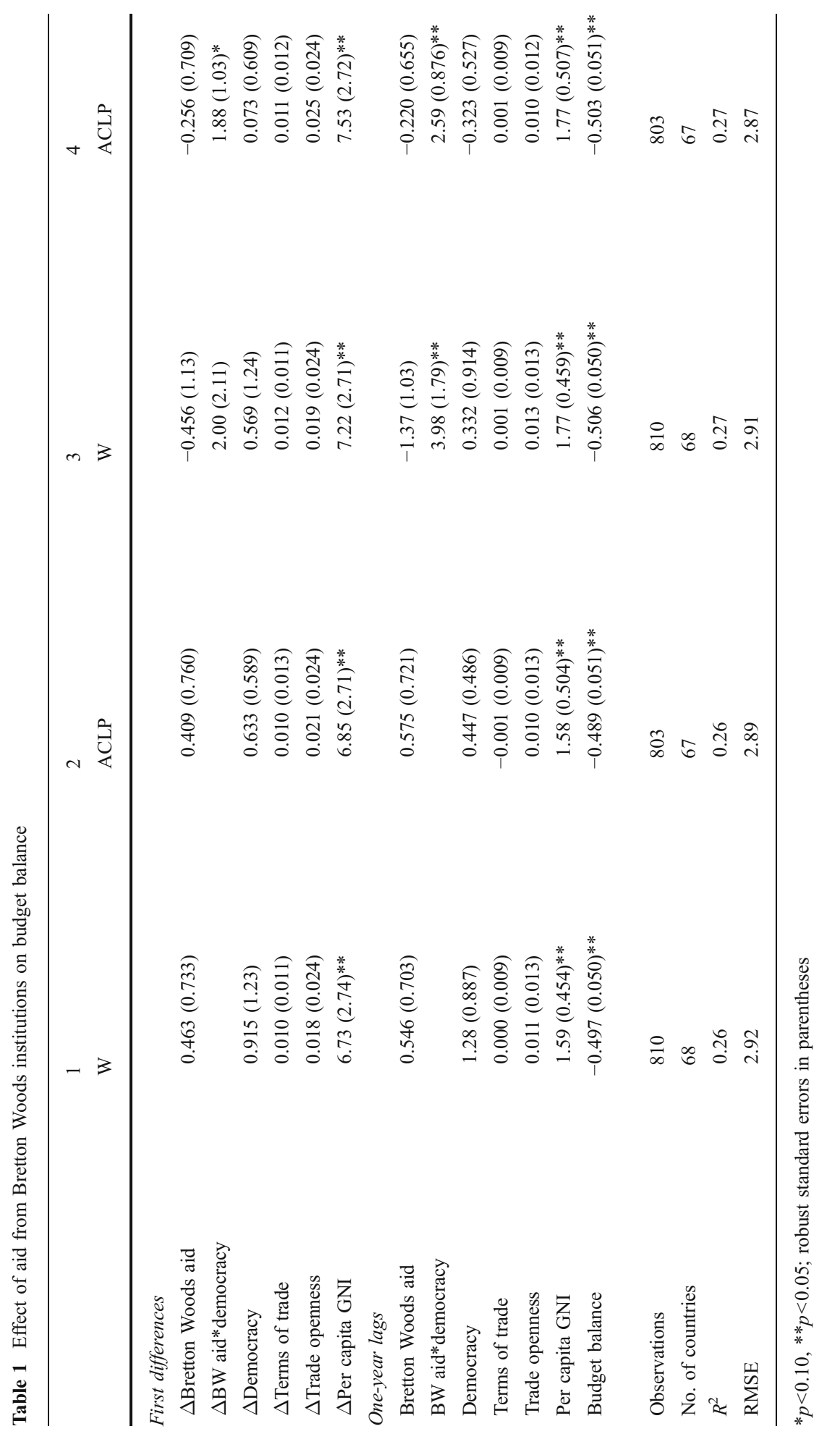


and 4 present results using the ACLP measure. The top half of each model presents coefficients for the first-differenced variables, which indicate the immediate effects of changes in these variables on fiscal balances. The bottom half of each model presents coefficients for the 1 year lagged variables, indicating the effects of these variables after approximately 1 year.

As shown in Table 1, the coefficients for the controls are generally in the expected direction, although not all are statistically significant. Economic growth has clear effects on fiscal balances. The coefficients on the first-differenced and lagged per capita income variables are all positive and significant, indicating that economic growth has immediate and one-year lagged positive effects on fiscal balances. The effects of terms of trade on fiscal performance are more ambiguous. The coefficients on the first-differenced and lagged terms of trade variables are positive as expected, but not significant. Finally, the coefficients on the first-differenced and lagged trade openness variables are similarly positive but not significant. This result may be due to collinearity between the measures for trade openness and economic development. When the latter are dropped, the coefficients for the lagged trade openness variable increase and their $p$ values range from 0.08 to $0.12 .^{10}$

Turning to the variables of interest, I start with models 1 and 2 which present the unconditional effects of Bretton Woods aid on the budget balance, i.e., the effects of Bretton Woods aid holding all other variables constant. In these models, the coefficients for the first-differenced and 1-year lagged Bretton Woods Aid indicators are positive but not significant, indicating that an increase in aid from the Bretton Woods institutions has no immediate or 1-year lagged unconditional effect on fiscal balances. This result is consistent with previous work that shows that, on average, aid has no effect on reform. The coefficients for the first-differenced and 1-year lagged Democracy indicators are also insignificant, indicating that level of democracy has neither immediate nor 1-year lagged effects on the budget balance. This result is not altogether surprising. Empirical studies on the relationship of regime type and reform present similarly ambiguous results. ${ }^{11}$

Models 3 and 4 examine the effects of Bretton Woods aid conditional on recipients' level of democracy. In these models, the coefficients on the first differenced Bretton Woods Aid*Democracy terms are positive, as hypothesized, however only that of model 4 is significant. Thus, it is ambiguous whether changes in aid from Bretton Woods institutions have immediate effects on fiscal balances conditional on recipients' level of democracy. Models 3 and 4 indicate more clearly, however, that aid from the Bretton Woods institutions has 1-year lagged conditional effects. Both coefficients on the 1-year lagged Bretton Woods Aid*Democracy terms are positive and significant. This indicates, as hypothesized, that the impact of aid from Bretton Woods institutions increases with recipients' level of democracy, and this impact occur after a 1-year lag.

Models 3 and 4 provide insight into the separate effects-immediate and 1-year lagged effects - of Bretton Woods aid on fiscal performance. Since we are most

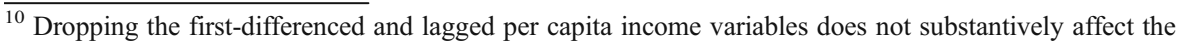
results for the variables of interest discussed below.

${ }^{11}$ For reviews on the determinants of reform including regime type, see Haggard and Webb (1993) and Rius and van de Walle (2003).
} 
interested in the total impact of aid, it is useful to determine aid's combined effects, i.e., aid's immediate and 1-year lagged effects, as well as any additional effects that might be realized after longer lags. This total effect and its corresponding standard error can be calculated by re-estimating models 3 and 4 using the Bewley (1979) transformation as suggested by De Boef and Keele (2008). This re-estimation provides us with coefficients referred to as LRMs which capture the total effects of the models' righthand side variables.

Table 2 presents the LRMs and corresponding standard errors based on models 3 and 4 of Table 1 . The results presented in Table 2 reinforce the conclusion that the impact of Bretton Woods aid on fiscal performance is conditional on recipients' level of democracy. The LRMs for the Bretton Woods Aid*Democracy terms are positive and significant, indicating that the total impact of Bretton Woods aid increases with recipients' level of democracy.

For a fuller understanding of this total effect, I plot aid LRMs across different values of regime type. Figure 1a plots the aid LRMs on the $y$-axis against different values of regime type on the $x$-axis based on the model using $\mathrm{W}$ as the regime measure while Fig. $1 \mathrm{~b}$ presents results using the ACLP measure. The solid line represents the total impact of aid on fiscal balances while the dashed lines represent the $90 \%$ confidence intervals. The coefficients show the total effect of a one-unit change in the natural logarithm of aid as a percent of GNI at different values of regime type. Since the ACLP measure is a dichotomous variable, aid coefficients are first calculated for regime type values of 0 and 1 . The aid coefficients for regime type values between 0 and 1 are then derived by linear interpolation.

The results of the two models are similar. First, when regime type equals zero, the aid coefficients are negative but not significant: the aid coefficients are below zero but the confidence intervals include zero on the $y$-axis. This indicates that aid to countries rated as most autocratic has no effect on their fiscal balances. Second, as level of democracy increases, the conditional aid coefficients increase. They are not, however, significantly different from zero for values up to approximately 0.75 on $\mathrm{W}$ and the ACLP measure. The $90 \%$ confidence intervals encompass 0 when $\mathrm{W}$ and the ACLP measure are between 0 and 0.75 . This indicates that IMF and World Bank aid has no significant impact on fiscal reform

Table 2 Effect of Bretton Woods aid on budget balance (long-run multipliers)

\begin{tabular}{lcc}
\hline & W & ACLP \\
\hline Bretton Woods aid & $-2.72(2.00)$ & $-0.437(1.29)$ \\
BW aid*democracy & $7.86(3.44)^{* *}$ & $5.14(1.71)^{* *}$ \\
Democracy & $0.655(1.81)$ & $-0.642(1.03)$ \\
Terms of trade & $0.003(0.017)$ & $0.002(0.018)$ \\
Trade openness & $0.025(0.025)$ & $0.020(0.025)$ \\
Per capita GNI & $3.50(0.867)^{* *}$ & $3.52(0.951)^{* *}$ \\
Budget balance & $-0.973(0.196)^{* *}$ & $-0.984(0.204)^{* *}$ \\
\hline
\end{tabular}

LRMs and standard errors based on Bewley transformation of models 3 and 4 in Table 1

$* p<0.10, * * p<0.05$; robust standard errors in parentheses 


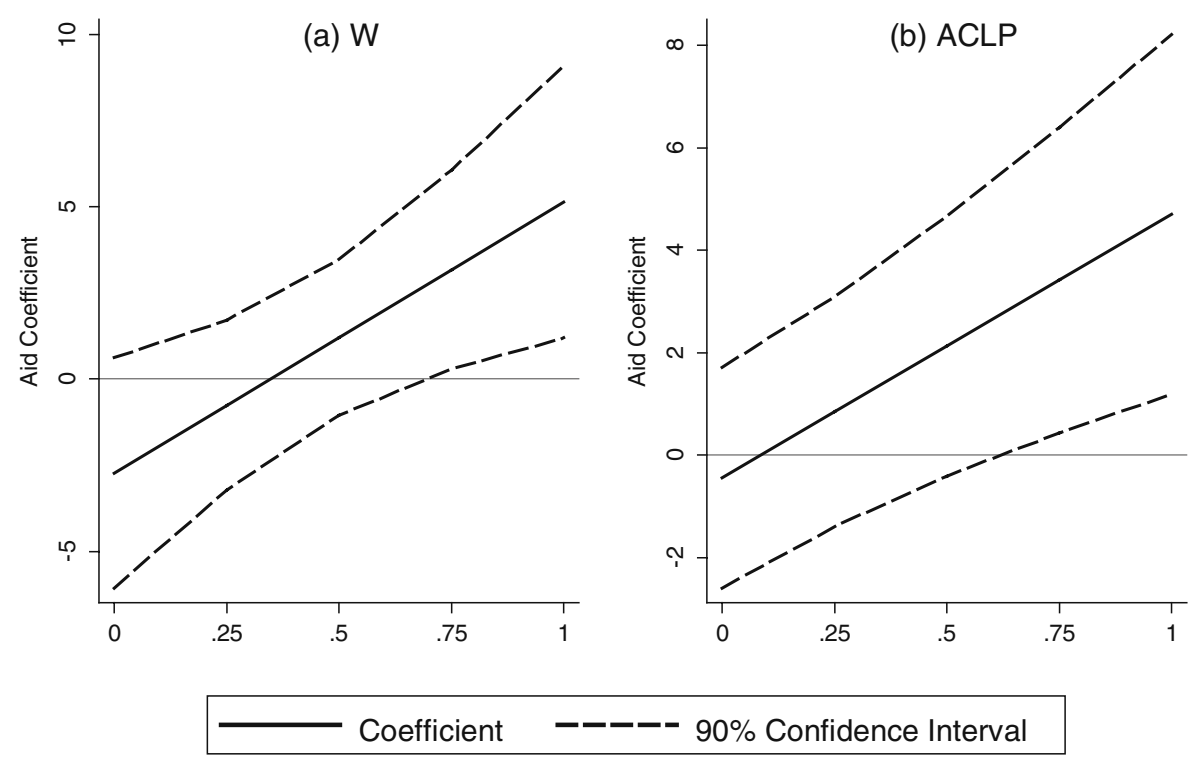

Fig. 1 Conditional effects of Bretton Woods aid on budget balance

in countries with zero to intermediate levels of democracy. This represents a substantial number of cases in the sample - $41 \%$ in the analysis with $\mathrm{W}$ and $51 \%$ in the analysis using the ACLP measure.

Finally, the conditional aid coefficients become positive and significant for countries with scores equal to or higher than 0.75 on W and the ACLP measure. More specifically, for countries that rank 0.75 on $\mathrm{W}$, a one standard deviation increase in the natural logarithm of aid as a percent of GNI causes a 3.17 percentage point improvement in a country's fiscal balance as a percent of GNI. A similar increase in aid to full democracies $(\mathrm{W}=1$ and $\mathrm{ACLP}=1)$ causes an improvement in a country's fiscal balance of 5.14 and 4.70 percentage points, respectively. Taken together, these results indicate that aid from Bretton Woods institutions promotes fiscal reform in more democratic countries, and the deficit-reducing impact of this aid increases with level of democracy.

In sum, the analysis shows that the impact of Bretton Woods aid on fiscal performance increases with recipients' level of democracy, and this result is consistent with the theory outlined above. Because the marginal impact of aid disbursements on autocrats' political survival is small, aid conditionality has little force on them. Autocrats are thus more likely than democrats to delay or forego reforms. Conversely, because aid disbursements always improve democratic leaders' survival prospects, the latter are more sensitive to aid conditionality. They are thus more likely than autocrats to adopt reforms required as conditions for future disbursements.

\section{Robustness Checks}

In this section, I probe the robustness of these results in two ways. First, I consider a powerful alternative explanation for variation in aid recipients' reform efforts - the 
level of conditionality imposed on countries. Second, I perform two-stage leastsquares instrumental variable analyses to correct for the possibility of endogeneity bias.

\section{Level of Conditionality as an Alternative Explanation}

Many studies show that bilateral donors' allocation of aid is in part driven by strategic interests (Alesina and Dollar 2000; Bueno de Mesquita and Smith 2006). Although multilateral organizations such as the IMF and World Bank are explicitly prohibited from using political considerations as criteria for their aid, previous work shows that countries of strategic interest to the USA are more likely to receive aid from the Bretton Woods institutions (Thacker 1999; Fleck and Kilby 2006; Harrigan et al. 2006). Moreover, recent work that focuses on IMF program participation (Stone 2004) shows that program conditions are less rigorously enforced on countries that are important to the IMF's major shareholders. This work suggests that fiscal conditions on aid from the World Bank may be similarly less stringent- or not as stringently enforced - on countries that are of strategic interest to developed country donors with influence over the Bank. ${ }^{12}$ If conditions on some countries are not as binding because they are of strategic value to countries with influence over the Bretton Woods institutions, then they may be less likely to adopt reforms. ${ }^{13}$ Work that fails to consider the value of developing countries to developed-country patrons may thus suffer from omitted variable bias.

To control for this possibility, I re-estimate models 3 and 4 in Table 1 with measures of developing countries' value to donors who have significant influence over the Bretton Woods institutions. Based on Stone's (2004) work, I assume that the measures are proxies for the level of conditionality imposed on developing countries. In particular, I consider ties between developing countries and the USA, France, and Britain. Ties to the USA are important because the USA enjoys a privileged decision-making position in the Bretton Woods institutions (Kahler 1990; Wade 2002), and as mentioned above, previous work shows that the IMF and World Bank respond to the political interests of the USA. I consider ties to France and Britain because they are among the more influential members on the Executive Boards of the Bretton Woods institutions with ongoing ties to extensive networks of former colonies (Woods 2001). These former colonies are likely aid recipients, and as Stone (2004) shows with respect to IMF programs, countries with ties to France and Britain experience less binding conditions.

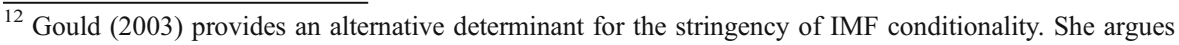
that if a borrower receives more supplementary financing from private financial institutions in creditor states, its fund program will be relatively less stringent. I tested for this effect by including a measure for lending from private financial institutions together with the other measures of international politics described below. The indicator - commercial and other bank lending as a percentage of GNI — is from the World Bank's World Development Indicators. Since none of the coefficients for this measure were significant, and the results for the aid variables were essentially unchanged, I excluded the variable in the models presented below.

${ }^{13}$ Theoretically, the strategic value of a client state may have a positive effect on reform. Developed country patrons may prefer that their client states adopt reforms. I thank one anonymous reviewer for bringing this point to my attention.
} 
Following Stone (2004), I measure the value of countries to the USA, France, and Britain in different ways. First, I use the amount of aid that developing countries receive from each developed country donor. Donors' distribution of aid across countries should reflect the priority that the former place on the latter, and the priority of the latter may influence the stringency of conditions imposed on them by the Bretton Woods institutions. Like the measure for aid from Bretton Woods institutions, I express these bilateral aid measures as a percentage of recipients' gross national income. US Aid ${ }_{i t}$, French $\mathrm{Aid}_{i t}$, and British $\mathrm{Aid}_{i t}$ thus represent net disbursements of the USA, France, and Britain, respectively, to country $i$ at time $t$ as a percentage of country $i$ 's GNI. Second, I employ a measure of similarity in foreign policy portfolios between developing countries and the USA, France, and Britain. I assume that countries that align themselves with influential members of the Bretton Woods institutions may be rewarded with less stringent conditions. Specifically, I employ Signorino and Ritter's (1999) S-Similarity scores between developing countries and the USA, France, and Britain. Table 3 presents results of these analyses. Columns 1, 3, 5, and 7 present results using $\mathrm{W}$ as the measure of democracy. Columns 2, 4, 6, and 8 use the ACLP regime measure. Each pair of models from columns 1 to 6 includes measures of ties to the USA, France, and Britain separately. Columns 7 and 8 include measures of ties to all three developed country patrons, except for $S$ scores between developing countries and Britain. I exclude these $S$ scores because they are highly correlated with those between developing countries and France (Pearson's $r=0.99$ ). To preserve space, the coefficients for controls in the initial analyses - terms of trade, trade openness, and economic development-are not presented, however, results for these controls are effectively unchanged.

Table 3 provides some support for the argument linking strategic value to developed country patrons and extent of reform. The coefficients for lagged $S$ scores between developing countries on one hand, and the US, France, and Britain on the other, are negative and significant in models 1,3 , and 5 . These results suggest that countries whose foreign policies are aligned with the US, France, and Britain are less likely to adopt fiscal reform. Ties to Britain, however, appear to have the most consistent effect on countries' fiscal performance. The coefficients for the firstdifferenced and lagged measures of aid from Britain are also negative and significant in models 5 and 6 , indicating that clients of Britain are less likely to reform. Moreover, when indicators for all measures of strategic value to developed country patrons are included in the model (columns 7 and 8), it is the coefficients for the first-differenced and lagged measures of aid from Britain that remain significant.

More importantly, Table 3 shows that the results of my initial analyses are robust to the inclusion of measures for the importance of countries to the USA, France, and Britain. All coefficients for the first-differenced and lagged Bretton Woods Aid variables are insignificant, indicating that conditional aid has no immediate or lagged effect on fiscal performance in autocracies. In contrast, all coefficients for the lagged Bretton Woods Aid*Democracy indicators are positive and significant, indicating that the lagged impact of Bretton Woods aid on fiscal performance increases with level of democracy. 


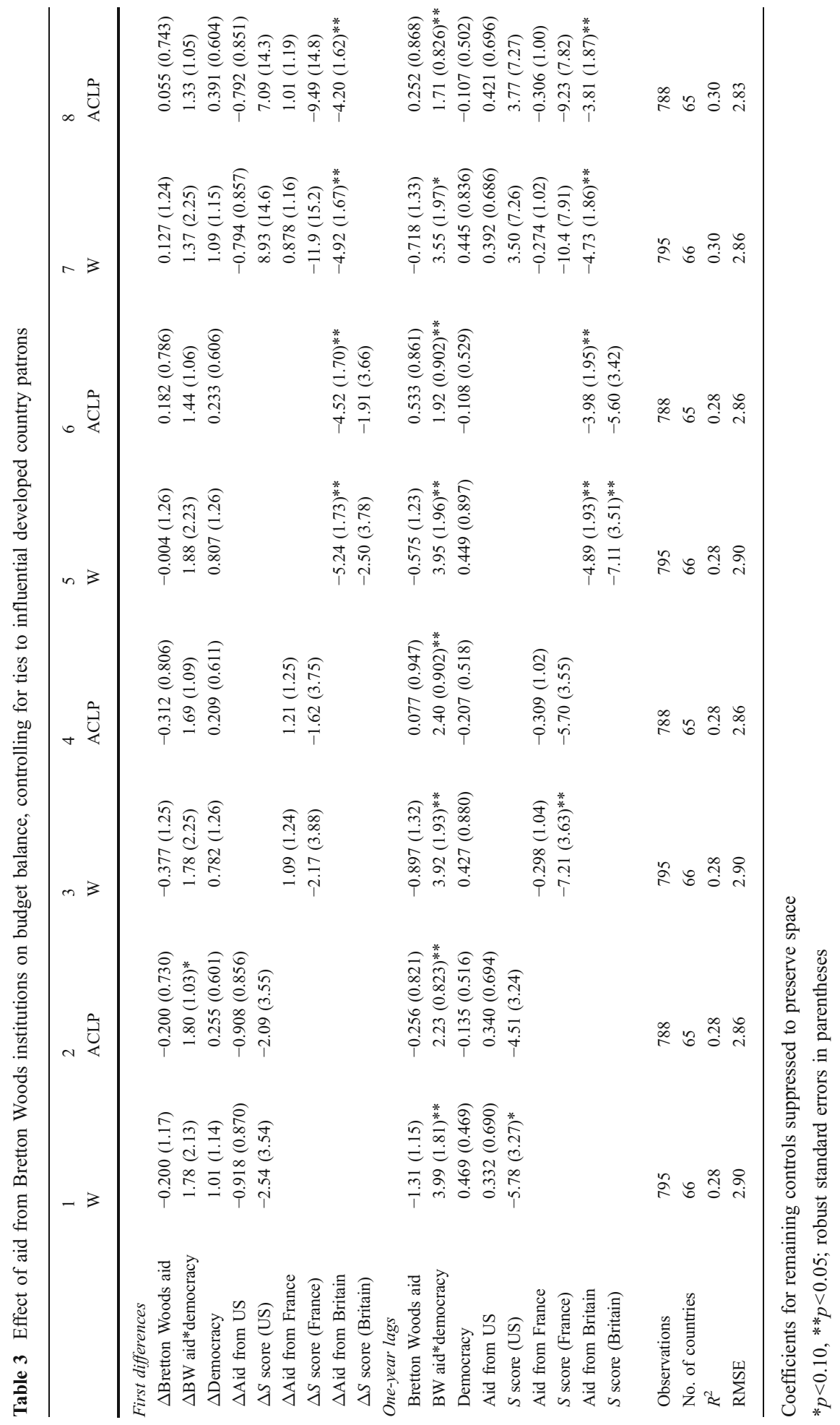




\section{Correcting for Potential Endogeneity Bias}

Some readers may be concerned that the results presented above suffer from endogeneity bias. There are several possible sources for this bias. First, countries that approach the Bretton Woods institutions are typically in fiscal trouble. Thus, aid from the Bretton Woods institutions is likely to be endogenous to recipient countries' fiscal performance. Second, Bretton Woods institutions may tailor conditions for success because they fear defaults. They may be especially lenient when negotiating with democracies, knowing that democratic governments are more likely to suffer popular backlash from austerity conditions. Thus, fiscal performance may be endogenous to the Bretton Woods institutions' decision to be lenient on democracies. Finally, Bretton Woods institutions may target countries that are likely to reform because they fear defaults, and if the institutions allocate more of their aid to democracies, this may be why conditional aid has a positive effect on fiscal performance only among democracies.

To correct for the possibility of endogeneity bias, I employ a two-stage least-squares instrumental variables (2SLS-IV) regression approach. Before describing the results of this analysis, however, it is worth evaluating on theoretical grounds the likelihood that my initial results are subject to the endogeneity problems listed above. In particular, I argue that the first two sources of bias are unlikely to generate the results that I obtained - the positive association between aid and reform in democracies. First, if the results are biased because aid flows to countries with deteriorating fiscal balances, the analysis would show a negative - or at best no - association between aid and fiscal performance. Non-random selection of aid recipients based on poor fiscal performance thus cannot explain my results. Second, if the results are biased because Bretton Woods institutions tailor their conditions for success, and they are especially lenient when negotiating with democracies, then we would expect conditional aid to be associated with less fiscal reform among democracies. As mentioned above, I obtain the opposite relationship; therefore, this source of endogeneity cannot explain my results. This leaves the third potential source of endogeneity - the possibility that the Bretton Woods institutions allocate more of their aid to democracies who are more likely to comply with fiscal policy conditions.

That said, as a robustness check, I employ a common way to correct for endogeneity problems-a 2 SLS-IV approach. In particular, I regress the potentially endogenous aid variables- $-\Delta$ Bretton Woods Aid, Bretton Woods Aid ${ }_{t-1}, \Delta$ Bretton Woods Aid*Democracy and Bretton Woods Aid $^{*}$ Democracy $_{t-1}$-against all other independent variables in the model and additional instruments. I then use the predicted values for the endogenous variables to estimate their effects on fiscal performance. ${ }^{14}$ Since regime type is one of the independent variables in the original model, the 2SLS-IV approach corrects for bias that may be due to Bretton Woods institutions' allocating aid based on regime type, as well as the endogeneity of conditional aid to fiscal performance.

The additional instruments that I employ have been shown in previous work to be good instruments for aid. Nooruddin and Simmons (2006) show for example that a principal determinant of participation in IMF programs is participation in previous years. Studies on aid similarly suggest that countries become dependent on aid, i.e., countries that receive aid in a given year are more likely to receive future disbursements. Thus, I

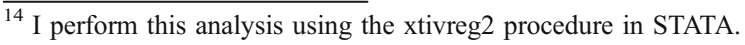


generate a variable - Previous Disbursement - that takes a value of one if a country received aid from either the World Bank or IMF in the previous year, and zero otherwise, and multiply the variable Previous Disbursement by Democracy. I then use lagged changes and levels of both variables as instruments for changes and levels of the potentially endogenous variables. Based on work by Burnside and Dollar (2000) and Knack (2004), I also include as instruments measures for the size and welfare of countries, in particular, the natural logarithm of population, income, and literacy rates and their interactions with the measures of democracy.

The results of the 2SLS-IV regressions are presented in Table 4. Models 1 and 2 include only the controls from the initial analysis and the aid variables of interest. Coefficients for the controls are not included for ease of presentation. Models 3 and 4 present results for the full model, which includes measures for aid recipients'

Table 4 2SLS-IV Regressions of budget balance on aid from Bretton Woods institutions

\begin{tabular}{|c|c|c|c|c|}
\hline & $\begin{array}{l}1 \\
\mathrm{~W}\end{array}$ & $\begin{array}{l}2 \\
\text { ACLP }\end{array}$ & $\begin{array}{l}3 \\
\mathrm{~W}\end{array}$ & $\begin{array}{l}4 \\
\text { ACLP }\end{array}$ \\
\hline \multicolumn{5}{|l|}{ First differences } \\
\hline$\Delta$ Bretton Woods aid & $1.86(5.27)$ & $4.05(2.74)$ & $3.61(4.88)$ & $5.12(3.38)$ \\
\hline$\Delta \mathrm{BW}$ aid*democracy & $4.41(8.18)$ & $1.00(2.90)$ & $5.08(6.84)$ & $0.166(2.76)$ \\
\hline$\Delta$ Democracy & $-0.005(2.04)$ & $0.364(0.964)$ & $0.362(1.76)$ & $0.872(0.967)$ \\
\hline$\Delta S$ score (US) & & & $1.70(16.4)$ & $2.66(15.7)$ \\
\hline$\Delta$ Aid from US & & & $-1.32(0.784)^{*}$ & $-1.17(0.820)$ \\
\hline$\Delta S$ score (France) & & & $-8.49(16.68)$ & $-9.31(15.9)$ \\
\hline$\Delta$ Aid from France & & & $-0.671(2.14)$ & $-0.043(2.05)$ \\
\hline$\Delta$ Aid from UK & & & $-9.59(2.65)^{* *}$ & $-7.73(2.50)^{* *}$ \\
\hline \multicolumn{5}{|l|}{ One-year lags } \\
\hline Bretton Woods Aid & $-2.94(2.99)$ & $0.419(1.74)$ & $-0.130(4.73)$ & $1.33(4.00)$ \\
\hline BW aid*democracy & $8.73(4.93)^{*}$ & $4.89(1.93)^{* *}$ & $8.87(4.87)^{*}$ & $3.63(2.11)^{*}$ \\
\hline Democracy & $-0.785(1.37)$ & $-0.768(0.662)$ & $-0.877(1.24)$ & $-0.405(0.635)$ \\
\hline$S$ score (US) & & & $2.02(8.51)$ & $3.56(8.37)$ \\
\hline Aid from US & & & $-0.418(0.870)$ & $-0.072(0.922)$ \\
\hline$S$ score (France) & & & $-10.2(9.04)$ & $-10.4(8.46)$ \\
\hline Aid from France & & & $0.801(2.18)$ & $-0.700(2.16)$ \\
\hline Aid from UK & & & $-5.82(3.16)^{*}$ & $-3.16(3.12)$ \\
\hline Observations & 740 & 733 & 725 & 718 \\
\hline No. of countries & 59 & 58 & 57 & 56 \\
\hline$R^{2}$ & 0.21 & 0.21 & 0.21 & 0.24 \\
\hline RMSE & 3.06 & 3.03 & 3.07 & 3.00 \\
\hline $\begin{array}{l}\text { Anderson CC LR statistic } \\
(p \text { value })\end{array}$ & $54.1(0.000)$ & $55.8(0.000)$ & $25.2(0.000)$ & $20.3(0.000)$ \\
\hline Hansen $J$ statistic ( $p$ value) & $7.15(0.306)$ & $8.11(0.230)$ & $6.81(0.338)$ & $7.62(0.314)$ \\
\hline
\end{tabular}

Coefficients for remaining controls suppressed to preserve space

$* p<0.10, * * p<0.05$, robust standard errors in parentheses 
importance to key developed country donors, i.e., proxies for the level of conditionality imposed on aid recipients. Models 1 and 3 use the winning coalition measure for regime type while models 2 and 4 present results using the ACLP measure.

Table 4 shows that the instrument set I employ is valid. The Hansen test shows that the model is overidentified: the null hypothesis that instruments are uncorrelated with the error term is not rejected. The $p$ values for the $J$ statistics range from 0.23 to 0.33. Moreover, the Anderson canonical correlations likelihood ratio (CC LR) test shows that the model is not underidentified, i.e., that the excluded instruments are correlated with the endogenous regressors. The null hypothesis of underidentification is rejected: the $p$ values for the corresponding Anderson CC LR statistics are all highly significant ( $p$ value $<0.000$ ).

Turning to the effects of the variables in the model, the results for the aid variables of interest are essentially unchanged. Across all four models, conditional aid has no significant immediate or 1-year lagged effect on fiscal performance in the most autocratic countries. The coefficients for the first-differenced and 1-year lagged measures of Bretton Woods aid are not significant. As in earlier regressions, the coefficients on the first-differenced interaction terms between Bretton Woods aid and democracy are insignificant, indicating that conditional aid has no immediate impact on democracies either. However, the coefficient on the lagged interaction terms between Bretton Woods aid and democracy are significant and positive, indicating that after at least 1 year, the impact of conditional aid on fiscal performance increases with recipients' level of democracy.

The estimates for the measures of countries' importance to the USA, France, and Britain are also similar to those in Table 3, columns 7 and 8 . The coefficients for three out of four measures of ties to Britain are negative and significant, indicating that countries of more importance to Britain are less likely to adopt fiscal reform. The estimates for the measures of importance to France remain statistically insignificant, indicating that ties to France have no effect on fiscal performance. Finally, the results for ties to the USA are now mixed. The coefficient on the first-differenced measure of bilateral aid from the USA is now significant at the $10 \%$ level in model 3 , however, the remaining three measures of ties to the US remain insignificant. This suggests that closer ties to the US do not systematically affect developing countries' fiscal performance.

In sum, the results of the 2SLS-IV analyses are similar to those of earlier regressions. They indicate that conditional aid's efficacy depends on recipient countries' level of democracy. More specifically, conditional aid promotes improvements in budget balances but only in democracies.

\section{Discussion}

Before concluding, it is worth discussing recent work by Nooruddin and Simmons (2006) which might seem to contradict my work. These authors examine the effects of IMF program participation on the composition of government spending and find that these effects are conditional on regime type. Specifically, they find that under IMF programs, democracies are more inclined than autocracies to cut spending on education and health. Although this result does not directly challenge my own-like me, they find that democracies are more likely than autocracies to cut spending in exchange for aid - it 
does raise questions about my causal argument. The selectorate theory on which my argument is based asserts that democrats are more likely than autocrats to provide public goods such as health and education (Bueno de Mesquita et al. 2003). If this is true, then we might expect democrats to be less likely than autocrats to cut health and education spending in response to an economic crisis. How, then, can we reconcile Nooruddin and Simmons's results with the logic of the selectorate model?

Nooruddin and Simmons themselves provide an explanation that is broadly consistent with the selectorate model. They argue and show that democracies spend more than autocracies on public goods in the first place, as the selectorate model predicts. Because democracies spend so much of their budgets on public goods, when faced with a crisis they cannot balance their budgets without cutting public good spending. In contrast, because autocracies spend so little on public goods, they cannot balance their budgets by making cuts in this category: there is simply not much to cut. Noorudin and Simmons's explanation for their results thus rests on the selectorate model's most basic claim: that democrats spend more than autocrats on public goods.

This claim enjoys strong empirical support. Citing Przeworski et al. (2000), Lake and Baum (2001), and Avelino et al. (2005), Mares and Carnes (2009:96) note in their review of social policy research that the literature supports "the contention that democracies spend more than nondemocracies on particular social programs." Studies on education also show that democracies spend more on education in Latin America (Brown and Hunter 2004; Huber et al. 2008), Africa (Stasavage 2005), and around the world (Ansell 2008). Other studies show that democracies spend more on social welfare (Huber et al. 2008; Rudra and Haggard 2005) and that democracies exhibit better health and education outcomes (Besley and Kudamatsu 2006; Nooruddin and Simmons 2006; Rudra and Haggard 2005). Nooruddin and Simmons's argument is thus not only consistent with the selectorate model but is also based on strong empirical foundations.

In addition to predicting the composition of spending, the selectorate model also implies that democrats are more likely than autocrats to cut spending in response to an economic crisis. In equilibrium, both autocrats and democrats spend the minimum required to stay in power. To spend more would be irrational, since leaders would be wasting resources that could otherwise be saved for a rainy day. Hence, according to the model, neither autocrats nor democrats can cut spending without risking losing office. This does not mean that leaders will be unseated by every negative shock. They can use "slack resources" stockpiled during good times to avoid spending cuts in bad times. ${ }^{15}$ Some leaders, however, have more slack resources than others. More specifically, because autocrats can maintain power with few resources, they amass considerable slack resources and can use these resources to avoid spending cuts in times of crisis. In contrast, democrats must spend all available resources to stay in power and thus have no slack resources when crises arise. The selectorate model thus generates two

\footnotetext{
$\overline{15}$ In other words, slack resources are not included in government budgets but are extra-budgetary resources that can be used to supplement the budget in times of crisis. This is inherent in the selectorate model's definition of slack resources and is consistent with anecdotal evidence on how leaders use surplus funds. Some leaders, such as Mobutu Sese Seko, transferred resources to nonstate institutions under their control—such as political parties and ostensibly charitable organizations - and instructed these institutions to distribute funds to supporters during elections or in times of crisis (Askin and Collins 1993, 78). Others have transferred resources to overseas bank accounts and have used the funds to purchase support when necessary.
} 
predictions about how leaders will respond to economic crises. First, democrats will make larger spending cuts than autocrats because, having no slack resources to draw upon, they have no choice. Second, as a consequence, democratic leaders are more likely to lose power. The first prediction is consistent with Nooruddin and Simmons (2006). The second is supported by several studies (e.g., Bueno de Mesquita et al. 2003; Chiozza and Goemans 2004, Marinov 2005).

This argument has important implications for aid conditionality. Because autocrats can draw on their own slack resources to weather crises, they are less dependent on foreign aid for survival. Since autocrats are less dependent on aid, they have less incentive to comply with onerous aid conditions. They are thus more likely to maintain current spending levels in defiance of aid conditions. In contrast, because democrats have no slack resources, they cannot avoid spending cuts in times of crisis. Their only hope of survival lies in outside resources such as foreign aid. This dependence on aid increases their incentives to comply with aid conditions. Although such conditions may be onerous, compliance with aid conditions would be preferable to the alternative of facing current-and future-crises without aid. This argument is supported by Kono and Montinola (2009), who show that an aidpursuing strategy enhances democrats' survival prospects.

\section{Conclusion}

Disillusionment with policy-based conditionality has prompted calls for its abolition. Some scholars advocate disbursing aid to countries that have already adopted market-oriented policies rather than conditioning aid on promises to reform policies (Burnside and Dollar 2000). Others recommend linking aid disbursements to outcomes such as progress in promoting growth or poverty reduction (Collier et al. 1997). These arguments are not without basis. Many studies show that foreign aid, which has been increasingly conditioned on policy reforms, has had no impact on policies (e.g., Burnside and Dollar 2000; Easterly 2005). Some show that aid has actually reduced incentives for reform (Heckelman and Knack 2005; Remmer 2004). Few of these studies, however, explicitly examines whether aid's effect on policy is mediated by recipient countries' regime type.

I argue that policy-based conditionality is effective but its efficacy depends on recipients' level of democracy. This is because the value of aid to governments - and therefore the likelihood of their complying with conditions - depends on the degree to which aid helps them maintain power, and recent work shows that the marginal impact of aid on political survival increases with level of democracy (Kono and Montinola 2009). Aid-for-policy deals should thus be more effective when offered to democratic governments. I test this theory by focusing on the impact of IMF and World Bank aid on fiscal reform. I show that aid from Bretton Woods institutions promotes fiscal reform but only in countries that are relatively democratic, and the deficit-reducing effect of aid increases with level of democracy.

My work has implications for the current debate on the efficacy of conditional aid. It suggests that if one of donors' goals is to promote fiscal reform, policy-based conditionality need not be abandoned altogether in favor of other aid allocation strategies. Aid conditioned on fiscal reform should be offered only to democratic 
governments. Whether aid's impact on other types of reform also depends on recipients' regime type is still an open question. Aid is typically tied to a program of diverse conditions, including trade liberalization, financial liberalization, privatization, and public sector reform. Future research could center on the conditional impact of aid and regime type on compliance with these other program conditions. Given the G8 industrialized nations' recent commitment to increase foreign aid, this line of research would be particularly timely.

Acknowledgments I thank David Bearce, Bruce Bueno de Mesquita, Bob Jackman, Yuch Kono, SCID reviewers and editors, and participants of the Workshop in Comparative Politics at Stanford University for helpful comments. Research for this paper was started while the author was a Campbell National Fellow, holding the Edward Teller Fellowship, at the Hoover Institution.

Open Access This article is distributed under the terms of the Creative Commons Attribution Noncommercial License which permits any noncommercial use, distribution, and reproduction in any medium, provided the original author(s) and source are credited.

\section{Appendix}

Table 5 Sample of countries

\begin{tabular}{|c|c|c|}
\hline Argentina & Haiti & Peru \\
\hline Belarus & Hungary & Poland \\
\hline Belize & India & Romania \\
\hline Bolivia & Indonesia & Russia \\
\hline Brazil & Iran & Rwanda \\
\hline Bulgaria & Israel & Senegal \\
\hline Burkina Faso & Jamaica & Singapore \\
\hline Burundi & Kazakstan & Slovak Republic \\
\hline Cameroon & Korea & Slovenia \\
\hline Chad & Latvia & South Africa \\
\hline Chile & Lesotho & Sri Lanka \\
\hline Colombia & Madagascar & St. Kitts-Nevis \\
\hline Congo, Rep. & Malaysia & St. Lucia \\
\hline Costa Rica & Mali & Syria \\
\hline Cote d'Ivoire & Mauritius & Thailand \\
\hline Croatia & Mexico & Togo \\
\hline Czech Republic & Moldova & Trinidad \& Tobago \\
\hline Dominican Republic & Morocco & Tunisia \\
\hline Egypt & Namibia & Turkey \\
\hline El Salvador & Nepal & Uruguay \\
\hline Ethiopia & Nicaragua & Venezuela \\
\hline Gabon & Niger & Yemen \\
\hline Gambia & Pakistan & Zambia \\
\hline Guatemala & Panama & Zimbabwe \\
\hline Guinea-Bissau & Paraguay & \\
\hline
\end{tabular}




\section{References}

Ahluwalia M.S. The IMF and the World Bank in the new financial architecture. In International Monetary and Financial Issues for the 1990s:New York: UNCTAD; 1999. Research Papers for the Group of Twenty-four.

Alesina A, Dollar D. Who gives foreign aid to whom and why? J Econ Growth. 2000;5(1):33-63.

Ansell B. Traders, teachers, and tyrants: democracy, globalization, and public investment in education. Int Organ. 2008;62:289-322.

Askin S, Collins C. External collusion with kleptocracy: can zaire recapture its stolen wealth? Rev Afr Polit Econ. 1993;57:72-85.

Avelino G, Brown D, Hunter W. The effects of capital mobility, trade openness and democracy on social spending in Latin America 1980-1999. Am J Polit Sci. 2005;49(3):625-41.

Besley T, Kudamatsu M. Health and democracy. Am Econ Rev. 2006;96(2):313-8.

Bewley RA. The direct estimation of the equilibrium response in a linear model. Econ Lett. 1979;3:35761.

Bird RM. Tax reform in Latin America: a review of some recent experiences. Lat Am Res Rev. 1992;27 (1):7-36.

Bräutigam D. Institutions, economic reform, and democratic consolidation in Mauritius. Comp Polit. 1997;30(1):45-62.

Brown DS, Hunter W. Democracy and human capital formation: education spending in Latin America, 1980 to 1997. Comp Polit Stud. 2004;37(7):842-64.

Bueno de Mesquita B., Smith A. A political economy of aid. Unpublished manuscript. 2006

Bueno de Mesquita B, Smith A, Siverson RM, Morrow JD. The logic of political survival. Cambridge, Mass.: MIT Press; 2003.

Burnside C, Dollar D. Aid, policies, and growth. Am Econ Rev. 2000;90(4):847-68.

Cheibub JA, Gandhi J. Classifying political regimes: a six-fold measure of democracies and dictatorships. Chicago: Prepared for the annual meeting of the American Political Science Association; September 2004.

Chiozza G, Goemans HE. International conflict and the tenure of leaders: is war still ex post inefficient? Am J Polit Sci 2004;48(3):604-619.

Collier P, Guillaumont P, Guillaumont S, Gunning JW. Redesigning conditionality. World Dev. 1997;25 (9):1399-407.

De Boef S, Keele L. Taking time seriously, dynamic regression models. Am J Polit Sci. 2008;52(1):184200.

Dijkstra AG. Technocracy questioned: assessing economic stabilisation in Nicaragua. Bull Lat Am Res. 1999;18(3):295-310.

Dijkstra AG. The effectiveness of policy conditionality: eight country experiences. Dev Change. 2002;33 (2):307-34.

Dollar D, Svensson J. What explains the success or failure of structural adjustment programmes? Econ J. 2000;110(466):894-917.

Dreher A. The development and implementation of IMF and world bank conditionality. HWWA Discussion Paper 165. Hamburg Institute of International Economics. 2002

Easterly W. The lost decades: developing countries' stagnation in spite of policy reform 1980-1998. J Econ Growth. 2001;6(2):135-57.

Easterly W. What did structural adjustment adjust? the association of policies and growth with repeated IMF and World Bank adjustment loans. J Dev Econ. 2005;76(1):1-22.

Feinberg RE. The changing relationship between the World Bank and the International Monetary Fund. Int Org. 1988; 42(3):545-560.

Feyzioglu T, Swaroop V, Zhu M. A panel data analysis of the fungibility of foreign aid. World Bank Econ Rev. 1998;12(1):29-58.

Fine B, Lapavitsas C, Pincus J. Development policy in the 21 st century :beyond the post-Washington consensus. Routledge Studies in Development Economics. London; New York: Routledge; 2001.

Fleck RK, Kilby C. World bank independence: a model and statistical analysis of US influence. Rev Dev Econ. 2006;10(2):224-240.

Kuczynski Godard Pedro-Pablo, John Williamson. After the Washington consensus: restarting growth and reform in Latin America. Washington, DC: Institute for International Economics; 2003.

Haggard S. The politics of adjustment-lessons from the IMFs extended fund facility. Int Org. 1985;39 (3):505-34. 
Haggard S, Webb SB. What do we know about the political economy of economic policy reform? World Bank Res Obs. 1993;8(2):143-68.

Harrigan J, Wang CG, El-Said H. The economic and political determinants of IMF and World Bank lending in the Middle East and North Africa. World Dev. 2006;34(2):247-70.

Heckelman J, Knack S. Foreign aid and market-liberalizing reform. World Bank Policy Research Working Paper:Washington, D.C.; 2005.

Huber E, Mustillo T, Stephens JD. Politics and social spending in Latin America. J Polit. 2008;70(2):420-36.

Ivanova A, Mayer W, Mourmouras A, Anayiotos G. What determines the success or failure of fund-supported programs. Paper presented at the Second Annual IMF Research Conference, November 29-30. 2001

Kahler M. The United States and the International Monetary Fund: declining influence or declining interest. In: Karns MP, Mingst KA, editors. The United States and multilateral institutions: patterns of changing instrumentality and influence. Boston: Unwin Hyman; 1990.

Killick T, Gunatilaka R, Marr A. Aid and the political economy of policy change. London; New York: Routledge; 1998.

Knack S. Does foreign aid promote democracy? Int Stud Q. 2004;48:251-66.

Koeberle SG. Should policy-based lending still involve conditionality? World Bank Res Obs. 2003;18 (2):249-73.

Kono DY, Montinola GR. Aid conditionality: does foreign aid support autocrats, democrats, or both? J Polit. 2009;71(2):704-18.

Lake D, Baum M. The invisible hand of democracy: political control and the provision of public services. Comp Polit Stud. 2001;34(6):587-621.

Mares I, Carnes ME. Social policy in developing countries. Annu Rev Polit Sci. 2009;12:93-113.

Marinov N. Do economic sanctions destabilize country leaders? Am J Polit Sci. 2005;49(3):564-576.

Mayer W, Mourmouras A. IMF conditionality and the theory of special interest politics. Comp Econ Stud. 2004;46:400-22.

Mosley P. A theory of conditionality. In: Mosley P, editor. Development finance and policy reform: essays in the theory and practice of conditionality in less developed countries. New York: St. Martin's Press; 1992.

Nooruddin I, Simmons JW. The politics of hard choices: IMF programs and government spending. Int Organ. 2006;60:1001-33.

Pack H, Pack JR. Foreign aid and the question of fungibility. Rev Econ Stat. 1993;75(2):258-65.

Przeworski A, Alvarez ME, Cheibub JA, Limongi F. Democracy and development: political institutions and wellbeing in the world, 1950-1990. New York: Cambridge University Press; 2000.

Remmer KL. Does foreign aid promote the expansion of government? Am J Polit Sci. 2004;48(1):77-92.

Rius A, van de Walle N. Political institutions and economic policy reform. paper prepared for presentation at the global development network workshop on understanding reform. 2003.

Rudra N, Haggard S. Globalization, democracy, and effective welfare spending in the developing world. Comp Polit Stud. 2005;38(9):1015-49.

Signorino CS, Ritter JM. Tau-b or not Tau-b: measuring the similarity of foreign policy positions. Int Stud Q. 1999;43:115-144.

Smith A, Vreeland JR. The survival of political leaders and IMF programs. In: Ranis G, Vreeland JR, Kosack S, editors. Globalization and the Nation state: the impact of the IMF and the World Bank. New York: Routledge; 2006.

Solimano A. Inflation and the costs of stabilization: historical and recent experiences and policy lessons. World Bank Res Obs. 1990;5(2):167-85.

Stasavage D. Democracy and education spending in Africa. Am J Polit Sci. 2005;49(2):343-58.

Stevenson Richard W. "8 Leaders Hail Steps on Africa and Warming." The New York Times 9 July 2005. 2005.

Stone RW. The political economy of IMF lending in Africa. Am Polit Sci Rev. 2004;98(4):577-91.

Thacker SC. The high politics of IMF lending. World Polit 52(1):38+; 1999.

Wade RH. US hegemony and the World Bank: the fight over people and ideas. Rev Int Polit Econ. 2002;9 (2):201-29.

Woods N. Making the IMF and the World Bank more accountable. Int Aff. 2001;77(1):83-100.

World Bank. The theory and practice of conditionality: a literature review. Background Paper for Review of World Bank Conditionality. Washington, D.C:World Bank; 2005.

Gabriella R. Montinola is an Associate Professor of Political Science at the University of California, Davis. Her research focuses on the sources of corruption and reform. Her work is published in journals including the British Journal of Political Science, Comparative Political Studies, the Journal of Democracy, the Journal of Politics, and Studies in Comparative International Development. 